\title{
PSYCHOLOGICAL RUPTURES IN DORIS LESSING'S THE GRASS IS SINGING
}

\author{
Atlantica Boruah \\ Research Student, Department of English, \\ Dibrugarh University, Dibrugarh, Assam, India
}

\begin{abstract}
The aim of this paper is to study the psychology of the protagonist Mary Turner of the novel The Grass is Singing by applying the concepts of Freudian Psychoanalysis such as the unconscious, id-ego-superego, repression, Oedipus Complex, etc. African writer Doris Lessing's choice of Mary Turner's character in her novel gives us a new way to read her novel. To read a text from a theoretical perspective is very relevant nowadays. This paper will try to touch the text and the Freudian psychoanalysis in a parallel manner and will try to inspect the psychological condition of the characters of the novel along with the protagonist.
\end{abstract}

Key words: Psychology, Doris Lessing, Mary Turner.

Cite this Article: Atlantica Boruah, Psychological Ruptures in Doris Lessing's the Grass is Singing, International Journal of Management, 11(12), 2020, pp 53-56.

http://iaeme.com/Home/issue/IJM?Volume=11\&Issue=12

\section{INTRODUCTION}

The reality in which we exist is nothing but a blurred space. Society always foregrounds the things which are regarded as ideals. But there is some hidden truth behind these ideals. The reality of human behavior is suppressed due to societal norms. Doris Lessing one of the most contemporary African British writers gained immediate success with her first novel The Grass is Singing (1950) which is a story of the character of Mary Turner, brought up in a community of conservative English settlers in South Africa, her loneliness and isolation, her inability to balance between personal relations and social forces which leads to her tragic end with severe mental disintegration and ultimately murder in the hands of native servant Moses.

Psychoanalysis gained its prominence with the discoveries of Sigmund Freud during the nineteenth century. He paved the way for psychology in literary studies. In the earlier days, the 'unconscious' in a man's psyche is not given due importance. But after the arrival of Freud's theory, the unconscious seems to be treated well. Human beings' life is chiefly formed by the unconscious drive which is always in a dilemma or in conflict with his reason and the values of the society. Freud also talks about three parts of the human psyche- the 'id', the 'ego', and the 'superego'. The 'id' Freud's favorite territory, is the area of instincts, dreams, 
desires, and all that does not come to the force of human consciousness. This is the unconscious part according to Freud. The 'ego' fight against the two enemies that are firstly it has to protect itself from the societal norms and at the same time, it has to control the demands of 'id' that is of the unconscious. The 'superego' can be defined as the conscience of human beings. Here 'id' swings between the 'ego' and the 'superego'. Mary Turner the protagonist of the novel deals with this kind of conflict throughout the novel.

Sexuality was the main point in Freud's theory which entails that most of man's repressed wishes are sexual. "Sexual normalities and abnormalities spring from the very earliest stages of human being; that is infantile sexual life".( Freudianism 14) The theory based infantile sexuality is known as Oedipus Complex. According to Freud Oedipus Complex plays a pivotal role in the shaping of sexuality and later in the behavior of the individual. Mary Turner in the novel grows her infantile sexual image as she saw in her parents. This leads to her repulsive attitude towards sex and male figures. The unfulfilled desires and impulses of every human being remain in the unconscious so they don't influence their daily lives. They seemed to be repressed but when the unconscious is in conflict with the conscious mind it results in psychological problems like neurosis and psychosis. In the novel although Mary tries to remove her past from her conscious mind but she is not able to remove it from her life as she again enters into the same life of poverty after her conjugal life Dick Turner.

The Grass is Singing portrays the sufferings of an individual, Mary Turner who finds it difficult to adjust in society. From the very beginning of the novel, we find the climax that the Black servant Moses murdered the protagonist of the novel Mary Turner. "The newspaper did not say much"(The Grass is Singing 9) - this is the sentence through which the novel begins. Through the description of this murder, the novel also focuses on the general atmosphere of the white world of Southern Rhodesia, now Zimbabwe, where the action of the novel is set. The narrative of the novel starts from the second chapter onwards through a flashback manner. Starting from her unhappy childhood to happy days in town, her desperate marriage at the age of thirty, then coming to the village with her husband Dick Turner, her brutal treatment towards the native workers, the economic depression of her family, the sale of Dick's farm to Charlie Slatter, her mental breakdown and her murder by the Black servant Moses.

From the very first chapter there is an irony in the narrative of the novel. The irony lies in the portrayal of Black servant Moses when he was not allowed to ride in the same car even with the dead body of Mary Turner as she is a white woman. "One could not put a black man close to a white woman, even if she were dead and murdered by him."(The Grass is Singing 24). This points out the White prejudice mentality of the people of Southern Rhodesia, which is basically a white settler community where the native people were not regarded as human beings at all. The blacks were only treated as others and there is not any kind of other relationship among white and a black person rather than master- slave relationship. This is ironic in the sense that the blacks whom they treated no better than a slave murdered the white woman Mary Turner which depicts a threat to the white settler community and through which the blacks tried to counter their existence. After committing the murder, Moses surrenders himself to the police instead of running away. This posits that he is not a fraud nor he wanted to do any kind of robbery in the house of Mary Turner. What is there beneath the murder is seemed to be a mystery for the readers while turning first few pages of the novel. In order to explore the background of Mary Turner one must have to examine her childhood. Her childhood was moulded with poverty and obsession which follows her till her death. Her alcoholic father, who was a railway pump man, always created drama in front of her by fighting with her mother. Mary had to witness the sufferings of her mother because of the unsuccessful life with her father. When she was sent to boarding school she was happy for the 
first time in her life because she was away from all those distresses of her childhood. Her painful and ruined experiences of childhood got repressed in her unconscious mind: "She was extremely happy,so happy that she dreaded going home at holiday times to her fuddled father, and her bitter mother.'(The Grass is Singing 34-35) Mary had the notion from her very childhood that the patriarch or father figure is very much violent. Her views regarding the relationship of her parents tend her to stay as spinster till the age of thirty.

Towards the adolescence period of Mary's life she was happy with her economic condition. Her new life in the town after completion of her education gave her a new set of friend circle and new way of living. She never hesitates to indulge in any sexual relationship with men. She was happy with her lifestyle, her daily routines prevent her from thinking about her own life. Her life shatters when she overhears her friends' conversations about her lifestyle. She was astounded at her friends gossiping about her childish behaviour and asexuality in a very informal manner. The incident left a great impact in her psyche that she took her decision to marry Dick Turner at the age of thirty. To prove her femininity in front of her friends she decided to marry Dick without her own consent. In the patriarchal society marriage is bound for a woman,whether she be a white or black she must have to fulfil all the norms to be a part of the society.

The conjugal life of Mary and Dick is not a happy one. They marry each other only to show the marital life to her friends but they are not at all happy with their own life. They themselves don't feel the same excitement for each other. There is a huge gap between the two. When Dick takes her to his farm, Mary was uncomfortable with her new life which was totally different from her life in the city. She hates the little house, the natives, Dick at times and most of all she hates the burning heat and the loneliness in the farm house. She tries to busy herself with the daily activities to kill her boredom and loneliness as Dick was busy in his farm. She finds herself living in a desert where she is suffering from extreme hot weather which suffocates her and this physical pain symbolizes her struggle against her repressed memories. Her marriage takes her to the same life from which she wants to escape. The loneliness and lack of understanding and excitement in the relationship tends her to stay in a different world although she was with Dick. She visualizes a hopeless future during such a situation. Although the Blacks enjoy the company of Dick in his farm but for the rude behaviour of Mary "the cook never lasted longer than a month"(The Grass is Singing 82) She not only hates the blacks but she can never be friendly with the people of her own community. She rejects the invitations of Mrs. Slatter and choses a lonely life. They kept themselves away from the society as they were financially poorer than the other White people of their locality. Although they are White but they were not capable of maintaining the ideological superiority of White masters and therefore they are criticized by their own White people. The difficulty to survive in such a condition tends the couple Dick and Mary to stay away from their own people.

After the arrival of Moses to their home as a cook, Mary's mental health deteriorates. He is the man whom Mary once whiplashed in the farm when he was resting for a while. Whenever Mary notices the scars in Moses' face she remembers the moment of whiplashing Moses. She feels that at any moment he may take any kind of revenge on her. The fact that she has once whiplashed him makes her unstable in her home itself. Later on she feels a growing sexual attraction towards Moses but still she tries to act as her master in her household. The clash between the sexual desire and the racial ideology seems to be mingled here. In Freudian terminology, Mary is trapped between her 'superego' and 'id'. Their relationship continues secretly even from the notice of Dick until an Englishman Tony Marshton arrives at the farm and he caught them at their intimate moment. The kind of relationship between the two Mary and Moses was very much complicated. Moses wants to 
help Mary who is under psychological trauma and in the same manner Mary surrenders herself to him only to get back the fatherly care which she was deprived of. The psychological depression in her tends her to come close to Moses through which she receives some kind of bliss. Towards the end of the novel we can see Mary's desire to get killed by Moses through which she can be relieved from all the sufferings and loneliness.

Towards the end of the novel we can see that Mary fails to balance between her personal desires with that of her racial and patriarchal ideologies leading to her psychological breakdown. Her traumatic childhood haunts her, the life after her marriage with Dick Turner enters her to a world of anxiety and loneliness. Lack of mental support from her husband makes her too close towards the black servant Moses. Mary surrenders herself to Moses due to his attractive physical and mental sketches. But she becomes conscious about her status and societal pressure for which she is trapped between her sexual desire and the racial ideology, in the Freudian term between the id and the superego which shapes her fractured psyche. She betrays her status as a white woman after coming into contact with Moses and transgresses the boundary of master-slave relationship. Mary undergoes constant conflict under the binaries of conscious and unconscious, white -black, which leads to her mental ruptures along with the tragic end. Through this novel Doris Lessing portrayed the ruptured psyche of the protagonist which happens only because of the societal norms and regulations. Society wants us to stay like this or that. When one tries to stay away from societal norms he or she has to suffer such kind of depression and frustration.

\section{CONCLUSION}

This paper will try to touch the text and the Freudian psychoanalysis in a parallel manner and will try to inspect the psychological condition of the characters of the novel along with the protagonist.

\section{REFERENCES}

[1] Hoffman, Frederick J. Freudianism and the Literary Mind. Louisiana: Louisiana State University Press, 1957.

[2] Nayar, Pramod K. Contemporary Cultural and Literary Theory. New Delhi: Pearson,2010.

[3] Lessing,Doris. The Grass is Singing. London: Harper Collins,2013.

[4] Georgescu, Elena Anca. "Cultural and Psychological Border Crossings in Doris Lessing 's The Grass is Singing.”. International Journal of Arts and Sciences. 2011.

[5] Wang, Joy. "White Postcolonial Guilt in Doris Lessing's 'The Grass Is Singing."” Research in African Literatures, vol. 40, no. 3, 2009, pp. 37-47. JSTOR, www.jstor.org/stable/40468135. Accessed 14 Aug. 2020. 